\title{
Sarcopenia and severity of non-alcoholic fatty liver disease
}

\author{
Josilda Ferreira CRUZ ${ }^{1}$, Yasmim Anayr Costa FERRARI ${ }^{1}$, Carla Perez MACHADO², \\ Nathalia Nascimento SANTANA ${ }^{1}$, Allan Victor Hora MOTA ${ }^{1}$ and Sonia Oliveira LIMA ${ }^{1}$
}

Received 11/6/2019

\begin{abstract}
Background - Non-alcoholic fatty liver disease is characterized by deposition of lipids in the hepatic parenchyma exceeding $5 \%$ of liver weight in the absence of other conditions, such as viral or alcoholic hepatitis and metabolic disease. Non-alcoholic fatty liver disease is the most common form of chronic liver disease in several countries. In addition to liver complications, recent studies have shown a relation between liver fat and sarcopenia. Objective - Determine the association between sarcopenia and the severity of non-alcoholic hepatic steatosis diagnosed by abdominal ultrasonography. Methods - A clinical, cross-sectional study was conducted with a sample of male and female adults (18 to 70 years of age) submitted to ultrasonography for the investigation of non-alcoholic hepatic steatosis. Evaluations were also performed for the determination of upper and lower limb muscle strength. Data analysis was performed with the aid of the SPSS 22.0 program and involved ANCOVA and the Bonferroni post hoc test, with $P$-value $<0.05$ considered indicative of statistical significance. Results - One hundred two patients were submitted to abdominal ultrasonography, $57.8 \%$ of whom presented some degree of non-alcoholic hepatic steatosis. The presence and degree of fatty liver infiltration were significantly associated with the sarcopenic index, determined by the ratio between upper and lower limb strength and BMI $(P=0.009$ and post-test $P=0.028$ for upper limbs; $P=0.006$ and post-test $P=0.013$ for lower limbs). Conclusion - In the present study, an association was found between the sarcopenic index and non-alcoholic hepatic steatosis, with an inversely proportional relation between this index and the severity of fatty infiltration. This finding offers further evidence of the metabolic interaction of the liver, adipose tissue and muscle.
\end{abstract}

HEADINGS - Non-alcoholic fatty liver disease. Sarcopenia. Ultrasonography. Muscle strength.

\section{INTRODUCTION}

Non-alcoholic fatty liver disease (NAFLD) is found in $73 \%$ to $90 \%$ of individuals with obesity ${ }^{(1)}$. NAFLD comprises a broad spectrum of diseases, such as simple steatosis, steatohepatitis and cirrhosis, which can progress to hepatocellular carcinoma ${ }^{(2)}$. NAFLD is defined as the deposition of lipids in the hepatic parenchyma exceeding $5 \%$ of liver weight in the absence of viral, alcoholic or metabolic etiologies. Several classes of lipids can accumulate in the liver, but triglycerides are the most frequently found in fatty infiltration ${ }^{(3)}$.

NAFLD is the most common form of chronic liver disease in several countries ${ }^{(4)}$. In industrialized nations, the prevalence of NAFLD determined by ultrasonography ranges from $20 \%$ to $40 \% \%^{(5)}$. The male sex, aging, systemic arterial hypertension and type II diabetes mellitus are associated factors; moreover, diet and lifestyle play a fundamental role in the pathogenesis of this disease ${ }^{(6)}$.

Besides the hepatic complications arising from NAFLD, in 2014, the Korean Sarcopenic Obesity Study published, for the first time, the possible relation between the loss of muscle mass, also known as sarcopenia, and the increasing prevalence of NAFLD unrelated to obesity and metabolic syndrome ${ }^{(7)}$. Defined by The European Working Group on Sarcopenia in Older People, sarcopenia is a syndrome characterized by the progressive, widespread loss of skeletal muscle tissue and strength, increasing the risk of adverse outcomes, such as physical disability, poor quality of life and even death ${ }^{(8)}$.
The term sarcopenic obesity was first defined by Baumgartner in the year 2000 and regards the co-presence of obesity and sarcopenia. The complex interaction of common pathophysiological mechanisms, such as increased proinflammatory cytokines, oxidative stress, insulin resistance and hormonal changes, mark the close relation between these two conditions ${ }^{(9)}$. To elucidate the metabolic axis among the liver, adipose tissue and muscle, studies have shown that myostatin, which is a member of the TGF-beta protein superfamily, is a muscle growth limiting factor and blocking this protein results in an increase in muscle mass as well as protection against hepatic steatosis and insulin resistance ${ }^{(10)}$.

The myostatin receptor activin IIBR was found in hepatic stellate cells, which synthesize collagen in the presence of chronic inflammation, promoting hepatic fibrosis. This raised questions in the scientific community as to whether fat in the liver promotes the activation of myostatin, resulting in the loss of muscle tissue, or whether sarcopenia, through the action of myostatin, promotes the fibrogenic effect of hepatic stellate cells ${ }^{(7,10)}$.

Therefore, the aim of the present study was to determine the association between sarcopenia and the severity of non-alcoholic hepatic steatosis diagnosed by abdominal ultrasonography.

\section{METHODS}

A clinical, cross-sectional study was conducted using data collected from November 2018 to January 2019 at an ultrasound 
service in the city of Aracaju, Brazil, after receiving approval by the local Ethics Committee (certificate number: 2.996.430). The study population was a convenience sample of patients who sought the ultrasound service either spontaneously or by medical indication and signed a statement of informed consent. Abdominal ultrasonography was performed using a good imaging resolution apparatus with a dynamic, convex transducer (with continuous, automatic image formation) operating at $3.75 \mathrm{MHz}$.

Male and female adults (age range: 18 to 70 years) evaluated by the same physician were included in the study. The exclusion criteria were alcohol consumption $\geq 140$ g/week for men and $\geq 70$ $\mathrm{g} /$ week for women, malignant liver tumor, previous liver disease, manifestations of a stroke and physical or cognitive impairment.

The preparation for abdominal ultrasonography was fasting for at least six hours and the use of an anti-gas agent. The hepatic parenchyma was analyzed and hepatic steatosis was classified as follows: Grade 0 - normal echogenicity; Grade 1-mild steatosis, with visualization of fine echoes in the hepatic parenchyma, normal visualization of diaphragm and intrahepatic vessels; Grade 2 - moderate steatosis, with diffuse increase in fine echoes, impaired visualization of intrahepatic vessels and diaphragm; Grade 3 accentuated steatosis, with considerable increase in fine echoes, impaired visualization or absence of intrahepatic vessels ${ }^{(11)}$.

After the ultrasound procedure, the patients were submitted to strength evaluations at the same service by a specialized physiotherapist. The body mass index (BMI) was calculated from weight and height. Knee extensor and elbow flexor strength tests were performed with the dominant limb. A LAFAYETTE manual dynamometer was used to record maximum strength, providing reliable, accurate, stable muscle strength readings. After a trial run to become familiarized with the procedure, three trials of each test were performed with maximum effort with a one-minute interval between readings. The mean of the three readings was recorded in Newtons. The tests were performed with the patient sitting in a chair with adjustable straight back: knee extension strength - measurement of force applied to the ankle with the leg not supported and the knee bent at $90^{\circ}$; elbow flexion strength - measurement of force applied to the anterior region of the forearm with the arm extended at $180^{\circ}$.

The sarcopenic index were calculated by the ratio of the forces of the elbow flexors and knee extensors by the BMI.

After correction for sex and age, the data were analyzed using SPSS version 22.0. ANCOVA was used to test the association between the sarcopenic index and non-alcoholic hepatic steatosis. The Bonferroni post-test was used to compare each grade separately and a $P$-value $<0.05$ was considered indicative of statistical significance.

\section{RESULTS}

One hundred six patients were recruited and four were excluded. Thus, the final sample was composed of 102 patients (mean age: $45.3 \pm 13.1$ years; range: 21 to 70 years). The female sex accounted for the majority of the sample $(n=65 ; 63.7 \%)$. Regarding the degree of fatty infiltration, 43 were classified with Grade $0(42.1 \%)$ and only five were classified with Grade $3(4.9 \%)$ (TABLE 1$)$.

Mean BMI was $28.7 \pm 5.1 \mathrm{~kg} / \mathrm{m}^{2}$ (range: 17.7 to $40.8 \mathrm{~kg} / \mathrm{m}^{2}$ ). Mean waist circumference was $92.7 \pm 14.9 \mathrm{~cm}$ (range: 46 to $127 \mathrm{~cm}$ ). Regarding the biochemical variables, mean blood sugar concentration was $103.1 \pm 61.8 \mathrm{mg} / \mathrm{dL}$ (range: 61 to $474 \mathrm{mg} / \mathrm{dL}$ ); mean HDL was $57.5 \pm 31.2 \mathrm{mg} / \mathrm{dL}$ (range: 25 to $219 \mathrm{mg} / \mathrm{dL}$ ); mean triglyceride
TABLE 1. Socio-demographic and clinical data of patients submitted to abdominal ultrasonography and muscle strength evaluations between November 2018 and January 2019 in Aracaju, Brazil.

\begin{tabular}{lcccc}
\hline $\begin{array}{l}\text { Variables / } \\
\text { categories }\end{array}$ & Mean & SD & Minimum & Maximum \\
\hline Age & $\begin{array}{c}45.3 \\
\text { Absolute } \\
\text { frequency }\end{array}$ & 13.1 & 21 & 70 \\
& & & Percentage & \\
Sex & 37 & & 36.2 & \\
Male & 65 & 63.7 & \\
Female & & & \\
Grade of steatosis & 43 & & 42.1 & \\
0 & 25 & & 24.5 & \\
1 & 29 & & 28.4 & \\
2 & 5 & & 4.9 & \\
3 & & &
\end{tabular}

SD: standard deviation

concentration was $146.0 \pm 74.1 \mathrm{mg} / \mathrm{dL}$ (range: 34 to $369 \mathrm{mg} / \mathrm{dL}$ ); mean total cholesterol was $209.3 \pm 48.5$ (range: 123 to 301 ); and mean LDL was $127.5 \pm 43.8$ (range: 50 to 216). Mean elbow flexor strength was $68.6 \pm 16.3$ (range: 35.3 to 115 ) and mean knee extensor strength was $98.7 \pm 28.9$ (range: 34 to 156 ) (TABLE 2).

TABLE 2. Anthropometric and biochemical characteristics of patients submitted to abdominal ultrasonography and muscle strength evaluations between November 2018 and January 2019 in Aracaju, Brazil.

\begin{tabular}{lcccc}
\hline Variable & Mean & SD & Minimum & Maximum \\
\hline $\begin{array}{l}\text { Waist circumference } \\
(\mathrm{cm})\end{array}$ & 92.7 & 14.9 & 46.0 & 127.0 \\
BMI & 28.7 & 5.1 & 17.7 & 40.8 \\
Blood sugar (mg/dL) & 103.1 & 61.8 & 61.0 & 474.0 \\
HDL (mg/dL) & 57.5 & 31.2 & 25.0 & 219.0 \\
TG (mg/dL) & 146.0 & 74.1 & 34.0 & 369.0 \\
Total cholesterol & 209.3 & 48.5 & 123.0 & 301.0 \\
LDL & 127.2 & 43.8 & 50.0 & 216.0 \\
$\begin{array}{l}\text { Elbow flexor } \\
\text { strength }\end{array}$ & 68.6 & 16.3 & 35.3 & 115 \\
$\begin{array}{l}\text { Knee extensor } \\
\text { strength }\end{array}$ & 98.7 & 28.9 & 34 & 156.2 \\
\hline
\end{tabular}

SD: standard deviation; BMI: body mass index; HDL: high density lipoprotein; TG: high triglyceride; LDL: Low-density lipoprotein.

TABLES 3 and 4 show the sarcopenic index of the upper and lower limbs according to sex and degree of non-alcoholic hepatic steatosis evaluated by abdominal ultrasonography. The association between the sarcopenic index and non-alcoholic fatty liver disease was statistically significant for the upper and lower limbs after correcting for sex and age ( $P=0.009$ and $P=0.006$, respectively), with the statistically significant post-test results $(P=0.028$ and $P=0.013$, respectively) (TABLE 5). 
TABLE 3. Upper limb sarcopenic index X grade of non-alcoholic hepatic steatosis diagnosed by abdominal ultrasonography in male and female patients evaluated between November 2018 and January 2019 in Aracaju, Brazil.

\begin{tabular}{lccc}
\hline Sex & Grade & Mean & SD \\
\hline \multirow{3}{*}{ Male } & 0 & 3.08 & 0.82 \\
& 1 & 2.70 & 0.55 \\
& 2 & 2.59 & 0.62 \\
& 3 & 2.12 & 0.25 \\
\multirow{3}{*}{ Female } & 0 & & \\
& 1 & 2.48 & 0.59 \\
& 2 & 2.12 & 0.80 \\
& 3 & 1.67 & 0.60 \\
\hline
\end{tabular}

SD: standard deviation.

TABLE 4. Lower limb sarcopenic index X grade of non-alcoholic hepatic steatosis diagnosed by abdominal ultrasonography in male and female patients evaluated between November 2018 and January 2019 in Aracaju, Brazil.

\begin{tabular}{lccc}
\hline Sex & Grade & Mean & SD \\
\hline \multirow{3}{*}{ Male } & 0 & 4.46 & 1.39 \\
& 1 & 3.93 & 1.05 \\
& 2 & 4.01 & 0.91 \\
& 3 & 2.29 & 0.63 \\
\multirow{3}{*}{ Female } & 0 & 3.74 & \\
& 1 & 3.06 & 1.09 \\
& 2 & 2.90 & 1.44 \\
& 3 & 2.30 & 0.77 \\
\hline
\end{tabular}

SD: standard deviation.

TABLE 5. Association between sarcopenic index and non-alcoholic hepatic steatosis diagnosed by abdominal ultrasonography in patients evaluated between November 2018 and January 2019 in Aracaju, Brazil.

\begin{tabular}{lcc}
\hline & Upper limbs & Lower limbs \\
\hline & $P=0.009$ & $P=0.006$ \\
Hepatic & Post-test & \\
Steatosis & $P=0.028$ & $P=0.013$ \\
\hline
\end{tabular}

\section{DISCUSSION}

According to Lee et al. (2016), NAFLD is one of the main conditions affecting the liver and is the most common of type of liver disease in the United States ${ }^{(12)}$ Yu et al. (2018) demonstrated an increase in the prevalence of NAFLD related to the increase in sedentary lifestyle and obesity rates as well as the aging of the population. The convergence of these factors results in the progressive loss of muscular mass and, consequently, sarcopenia ${ }^{(13)}$.

The present study used muscle strength tests (dynamometry) to evaluate sarcopenia, although dual emission X-ray absorptiometry (DXA) is the most widely used method for this evaluation. Although DXA is an efficient technique for measuring body composition and muscle mass, it is not applicable to daily clinical practice, because it is expensive, involves ionizing radiation and has restrictions in terms of space and body size ${ }^{(14,15)}$. Thus, there has been increasing support for dynamometry due to the greater accessibility related to its low cost, availability and ease of use ${ }^{(16,17)}$. The Lafayette manual muscle testing dynamometer, which was used in the present study, is a handheld ergonomic device used for the objective quantification of muscle strength and is considered an accessible alternative for the clinical setting ${ }^{(18,19)}$.

Liver biopsy is considered the gold standard for the diagnosis of NAFLD. However, due to its invasive nature and risk of complications, it should not be performed as screening tool for the population. In contrast, ultrasound is the most frequently indicated for the diagnosis and evaluation of non-alcoholic hepatic steatosis due to the fact that it is a non-invasive, low-cost modality that is widely available ${ }^{(20)}$. A bright liver image, which is due to the hyperechogenicity of hepatic parenchyma with thin and compact echoes on the ultrasound exam, is considered characteristic of hepatic steatosis. Studies have documented sensitivity of $83 \%$ to $94 \%$ and specificity of $84 \%$ to $100 \%$ for this examination in relation to liver biopsy ${ }^{(21)}$.

In the present study, non-alcoholic hepatic steatosis was significantly associated with the sarcopenic index of the upper and lower limbs. The results of the Korean Sarcopenic Obesity Study, which was the first work to demonstrate the association between NAFLD and sarcopenia, also showed a significant increase in hepatic fatty infiltration when sarcopenia was found in obese and non-obese patients. In a cohort study of 124 young adults, Hong et al. (2014) demonstrated a greater possibility of developing NAFLD in individuals with lower muscle mass and sarcopenia was related to an increased risk of advanced liver fibrosis ${ }^{(7)}$. Guichelaar and Charlton (2014) report that physiological changes that result in NAFLD are capable of simultaneously generating sarcopenia ${ }^{(22)}$. The complex interaction of common pathophysiological mechanisms, such as the increase of proinflammatory cytokines, oxidative stress, insulin resistance and hormonal changes, mark the close relation between these two conditions ${ }^{(23)}$.

In the present study, a statistically significant association was found between higher grades of steatosis and sarcopenia, as evidenced by the lower sarcopenic indexes of the upper and lower limbs. Lee et al. (2016) found a weak association between simple steatosis, which has a good long-term prognosis, and the loss of muscle mass. However, the small proportion of these individuals who progressed to necroinflammatory manifestations and significant fibrosis had true sarcopenia ${ }^{(12)}$. Physiological changes result in the progression of NAFLD, with production of interleukin 6 and TNF-alpha. These cytokines are responsible for greater proteolysis and consequent muscle degradation, with the release of myostatin, which, in a vicious cycle, contributes to the greater progression of hepatic steatosis and the formation of fibrosis ${ }^{(7,10)}$.

A limitation of the present study was the use of ultrasound as the only method for diagnosing NAFLD. However, it is a noninvasive method that, according to criteria established in the pertinent literature, enables diagnosing and scoring hepatic fatty infiltration.

\section{CONCLUSION}

In the present study, an association was found between the sarcopenic index and non-alcoholic hepatic steatosis, with an inversely proportional relation between this index and the severity of fatty infiltration. This finding offers further evidence of the metabolic interaction of the liver, adipose tissue and muscle. 


\section{Authors' contribution}

Cruz JF: study conception and design, data acquisition, analysis and interpretation of data, statistical analysis and writing of manuscript. Ferrari YAC, Machado CP, Santana NN, Mota AVH: data collection, analysis and interpretation of the data and writing of manuscript. Lima SO: conception and design of the research, analysis and interpretation of the data, writing of text and critical revision of manuscript.

\section{Orcid}

Josilda Ferreira Cruz. Orcid: 0000-0001-5161-9717. Yasmim Anayr Costa Ferrari. Orcid: 0000-0003-1766-341X. Carla Perez Machado. Orcid: 0000-0002-7038-157X. Nathalia Nascimento Santana. Orcid: 0000-0002-7272-9787. Allan Victor Hora Mota. Orcid: orcid.org/0000-0001-6612-4653. Sonia Oliveira Lima. Orcid: 0000-0002-3257-2412.

Cruz JF, Ferrari YAC, Machado CP, Santana NN, Mota AVH, Lima SO. Sarcopenia e gravidade da doença hepática gordurosa não-alcoólica. Arq Gastroenterol. 2019;56(4):357-60.

RESUMO - Contexto - A doença hepática gordura não-alcoólica caracteriza-se pela deposição de lipídios no parênquima hepático, excedendo 5\% do peso do fígado na ausência de outras afecções como hepatites virais, alcoólicas ou doenças metabólicas. A doença hepática gordura não-alcoólica tem sido observada como a forma mais comum de doença hepática crônica em diversos países. Além das complicações hepáticas, estudos recentes têm demonstrado a relação entre a presença de gordura hepática e a sarcopenia. Objetivo - Determinar a associação entre a sarcopenia e a gravidade da esteatose hepática não-alcoólica diagnosticada pela ultrassonografia abdominal. Métodos - Estudo clínico e transversal com amostra de pacientes de ambos os sexos, de 18 a 70 anos de idade, diagnosticados como portadores ou não de esteatose hepática não-alcoólica pela ultrassonografia e submetidos à avaliação da força muscular dos membros superiores e inferiores. Os dados foram inseridos no programa estatístico SPSS 22.0, analisados através do teste ANCOVA e pós-teste de Bonferroni, sendo considerado significante $P<0,05$. Resultados - Foram avaliados pela ultrassonografia abdominal 102 pacientes e destes, 57,8\% apresentaram algum grau de esteatose hepática não-alcoólica. A presença e os graus da infiltração gordurosa no fígado tiveram associação estatisticamente significativa com o índice sarcopênico, determinado pela razão entre força muscular dos membros superiores e inferiores e o IMC ( $P=0,009$ e pós-teste $P=0,028 \mathrm{MMSS} ; P=0,006$ e pós-teste $P=0,013 \mathrm{MMII})$. Conclusão - Observou-se associação entre o índice sarcopênico e a presença de esteatose hepática não-alcoólica, com relação inversamente proporcional entre esse índice e a gravidade da infiltração gordurosa, reforçando a interação do eixo metabólico entre fígado, tecido adiposo e músculo.

DESCRITORES - Hepatopatia gordurosa não-alcoólica. Sarcopenia. Ultrassonografia. Força muscular.

\section{REFERENCES}

1. Arslan N. Obesity, fatty liver disease and intestinal microbiota. World J Gastroenterol. 2014;20:16452-63.

2. Cleveland E, Bandy A, Vanwagner LB. Diagnostic Challenges of Nonalcoholic Fatty Liver Disease/Nonalcoholic Steatohepatitis. Clin Liver Dis (Hoboken) 2018;11:98-104.

3. Cotrim HP, Parise ER, Figueiredo-Mendes C, Galizzi-Filho J, Porta G, Oliveira CP. Nonalcoholic fatty liver disease Brazilian Society of Hepatology Consensus Arq Gastroenterol. 2016:53:118-22.

4. Fan JG, Kim SU, Wong VW. New Trends on Obesity and NAFLD in Asia. J Hepatol. 2017;67:862-73.

5. Williams CD, Stengel J, Asike MI, Torres DM, Shaw J, Contreras M. Prevalence of nonalcoholic fatty liver disease and nonalcoholic steatohepatitis among a largely middle-aged population utilizing ultrasound and liver biopsy: a prospective study. Gastroenterology. 2011;140:124-31.

6. Pang Q, Zhang J, Song S, Qu K, Xu X, Liu S, et al. Central obesity and nonalcoholic fatty liver disease risk after adjusting for body mass index. World $J$ Gastroenterol. 2015;21:1650-62

7. Hong HC, Hwang SY, Choi HY, Yoo HJ, Seo JA, Kim SG, et al. Relationship between sarcopenia and nonalcoholic fatty liver disease: the Korean Sarcopenic Obesity Study. Hepatology. 2014;59:1772-8.

8. Zhai Y, Xiao Q. The Common Mechanisms of Sarcopenia and NAFLD. Biomed Res Int. 2017;2017:6297651.

9. Baumgartner RN. Body Composition in Healthy aging. Ann N Y Acad Sci. 2000;904:437-48.

10. Harris-Love MO, Monfaredi R, Ismail C, Blackman MR, Cleary K. Quantitative Ultrasound: Measurement Considerations for the Assessment of Muscular Dystrophy and Sarcopenia. Front Aging Neurosci. 2014;14:172.

11. Saadeh S, Younossi ZM, Remer EM. The utility of radiological imaging in nonalcoholic fatty liver disease. Gastroenterology. 2002;123:745-50.

12. Lee Y, Kim SU, Song K, Park JY, Kim DY, Ahn SH, et al. Sarcopenia is associated with significant liver fibrosis independently of obesity and insulin resistance in nonalcoholic fatty liver disease: nationwide surveys (KNHANES 2008-2011). Hepatology. 2016;63:776-86.
13. Yu R, Shi Q, Liu L, Chen L. Relationship of sarcopenia with steatohepatitis and advanced liver fibrosis in non-alcoholic fatty liver disease: a meta-analysis. China: BMC Gastroenterology. 2018;18:51.

14. Ismail C, Zabal J, Hernandez HJ, Woletz P, Manning H, Texeira C, et al. Diagnostic ultrasound estimates of muscle mass and muscle quality discriminate between women with and without sarcopenia. Front Physiol. 2015;6:302.

15. Ticinesi A, Meschi T, Narici MV, Lauretani F, Maggio M. Muscle Ultrasound and Sarcopenia in Older Individuals: A Clinical Perspective. J Am Med Dir Assoc. 2017; 18:290-300.

16. Bredella MA, Ghomi RH, Thomas BJ, Torriani M, Brick DJ, Gerweck AV, et al. Comparison of DXA and CT in the assessment of body composition in premenopausal women with obesity and anorexia nervosa. Obesity. 2010;18:2227-33.

17. Giusto M, Lattanzi B, Albanese C, Galtieri A, Farcomeni A, Giannelli V, et al. Sarcopenia in liver cirrhosis: the role of computed tomography scan for the assessment of muscle mass compared with dual-energy X-ray absorptiometry and anthropometry. Eur J Gastroenterol Hepatol. 2015;27:328-34

18. Stark T, Walker B, Phillips JK, Fejer R, Beck R. Hand-held dynamometry Correlation with the Gold Standard Isokinetic Dynamometry: A Systematic Review. PM R. 2010;3:472-9.

19. Vermeulen J, Neyens JCL, Spreeuwenberg MD, Van Rossum E, Hewson DJ, De Witte LP. Measuring grip strength in older adults: comparing the grip-ball with the Jamar dynamometer. J Geriatr Phys Ther. 2015;38:148-53.

20. Tarzamni MK, Khoshbaten M, Sadrarhami S, Daneshpajouhnejad P, Jalili J, Gholamian M, et al. Hepatic Artery and Portal Vein Doppler Indexes in Non-alcoholic Fatty Liver Disease Before and After Treatment to Prevent Unnecessary Health Care Costs. International Journal of Preventive Medicine. 2014;5:472-7.

21. Almeida AA, Cotrim HP, Barbosa DBV, Athayde LGM, Santos AS, Bitencourt $\mathrm{AGV}$, et al. Fatty liver disease in severe obese patients: Diagnostic value of abdominal ultrasound. World J Gastroenterol. 2008;14:1415-8.

22. Guichelaar MMJ, Charlton MR. Decreased muscle mass in nonalcoholic fatty liver disease: new evidence of a link between growth hormone and fatty liver disease? Hepatology. 2014;59:1668-70.

23. Choi KM. Sarcopenia and Sarcopenic Obesity. Am J Physiol Endocrinol Metab. 2013;28:86-9.

\section{(cC) $\mathrm{BY}-\mathrm{NC}$}

